УДК 351.86:305:316.7

https://doi.org/10.52058/2708-7530-2021-9(15)-142-151

Марутян Кристина Каренівна аспірантка кафедри глобальної та національної безпеки, ННІ Публічного управління та державної служби КНУ імені Тараса Шевченка, головний спеціаліст відділу контенту ДОАР МВС України, вул. Богомольця, 10, м. Київ, 01601, тел.: (096) 643-96-96, e-mail: carenovna12@gmail.com, https://orcid.org/0000-0002-6208-5586

\title{
КУЛЬТУРА ГЕНДЕРНО ЧУТЛИВОЇ КОМУНІКАЦІЇ В СЕКТОРІ БЕЗПЕКИ І ОБОРОНИ
}

Анотація. У статті розглянуто зусилля міжнародних організацій (НАТО, ООН, ЮНІСЕФ) та державних інституцій провідних країн світу щодо інтеграції на стратегічному рівні питання гендерно чутливих комунікацій.

Також проаналізовано використання інтолерантних гендерних комунікацій, що спрямовані на приниження гідності людини або спільнот.

Проведене дослідження дозволяє стверджувати, що питання гендерно чутливих комунікацій на стратегічному рівні важливо інтегрувати в доктрини, програми, положення інститутів сектору безпеки і оборони; планувати державну політику з координації гендерно чутливої комунікації та розвивати міжвідомчу взаємодію 3 урахуванням аспектів гендерної чутливості; внести зміни до установчих документів безпекових інституцій щодо закріплення офіційного вживання фемінітивів (іменників жіночого роду на позначення людини за професією, посадою чи видом занять, що є парними до іменників чоловічого роду) на позначення професій, посад та військових звань.

Поряд із цим, на основі вивчення різних стратегій поступового реформування мови - фемінізації (послідовне вживання фемінітивів і відповідне уникнення загального чоловічого роду) і нейтралізації, було проаналізовано законодавчі зміни до національного класифікатора професій, яким дозволено використовувати фемінітиви. Також наведено успішний кейс лобіювання антидискримінаційного підходу у реформі сектору безпеки від Державної служби з надзвичайних ситуацій України, яка розробила академічний словник фемінітивів.

На підставі всебічного наукового аналізу обраної проблеми, запропоновано авторське визначення поняття «гендерно чутливі комунікацій».

Дослідження показало, що стратегія інтегрування гендерно чутливих комунікацій повинна супроводжуватися відповідною гендерно чутливою освітою персоналу сектору безпеки і оборони задля формування гендерної культури фахівців сфери національної безпеки.

Ключові слова: гендерна чутливість, сектор безпеки і оборони, гендерно чутлива комунікація, гендерно нейтральна мова, гендерна рівність. 
Marutyan Krystyna Karenivna Graduate student of the Department of Global and National Security, Institute of Public Administration and Civil Service of Taras Shevchenko National University, Chief Specialist of the Content Department of the Ministry of Internal Affairs of Ukraine, Bogomolets St., 10, Kyiv, 01601, tel .: (096) 643-96-96, e-mail: carenovna12@gmail.com, https://orcid.org/0000-0002-6208-5586

\title{
CULTURE OF GENDER SENSITIVE COMMUNICATION IN THE SECURITY AND DEFENSE SECTOR
}

\begin{abstract}
The article examines the efforts of international organizations (NATO, UN, UNICEF) and state institutions of the world's leading countries to integrate gender-sensitive communications at the strategic level.

The use of intolerant gender communications aimed at degrading human or community dignity is also analyzed.

The study suggests that the issue of gender-sensitive communications at the strategic level is important to integrate into the doctrines, policies, regulations of the security and defense sector; plan and coordinate gender-sensitive communications at both the state and interagency level, taking into account aspects of gender sensitivity; make changes to the constituent documents of security institutions to establish the official use of femininities to denote professions, positions and military ranks.

In addition, based on the study of various strategies of gradual language reform feminization (consistent use of femininities and the corresponding avoidance of the general masculine gender) and neutralization, legislative changes to the national classifier of professions that allow the use of femininities were analyzed. There is also a successful case of lobbying for an anti-discrimination approach to security sector reform by the State Emergency Service of Ukraine, which has developed an academic dictionary of femininities.
\end{abstract}

Based on a comprehensive scientific analysis of the selected problem, the author's definition of the concept of "gender-sensitive communications" is proposed.

The study showed that the strategy of integrating gender-sensitive communications should be accompanied by appropriate gender-sensitive education of security and defense personnel in order to form a gender culture of citizens.

Keywords: gender sensitivity, security and defense sector, gender sensitive communication, gender neutral language, gender equality.

Постановка проблеми. Представлення матеріалів про жінок у засобах масової інформації залишається досить стереотипним і дискримінаційним. За даними моніторингу новин восьми загальнонаціональних телеканалів, десяти загальноукраїнських Інтернет-видань та семи друкованих видань, який було проведено громадськими організаціями «Інститут масової інформації» та «Детектор медіа» у жовтні 2017 р. на замовлення Національного демократичного інституту, ролі експертів журналісти залучають жінок лише у 19 \% випадків[1]. 
Причому найчастіше жінки коментують соціальні теми, виступають учасниками кримінальної хроніки або «жовтих» новин, у той час як чоловіки коментують політичні та економічні теми.

Приблизно така ж динаміка збереглася і в 2020 році. Ця статистика $\epsilon$ сигналом до втілення змін, що спрямовані на формування нового світогляду щодо ролі жінки в суспільстві загалом і в секторі безпеки і оборони зокрема.

Шлях трансформацій, яким йдуть сьогодні більшість європейських держав світу, відповідає одному з найважливіших трендів XXI століття - формуванню культури гендерно чутливої комунікації. Це передбачає побудову нової гнучкої системи статеворольової ідентифікації (комунікативної поведінки), яка не визнаватиме і не підтримуватиме контроверсійних суджень стосовно ролі жінки в суспільстві.

В Іспанії битва за гендерно чутливу мову розпочалась у 1930 роки, коли такі жінки, як Клара Кампоамор, яка виборювала жіноче виборче право, та Долорес Ібарурі, яка в 1944 стала Першим секретарем Комуністичної партії Іспанії та лідером антифашистського рух. Деякі словники, зокрема німецький Duden [2] наприкінці минулого року почав вносити зміни в статті на своєму веб-сайті для іменників, які стосуються людей - всього їх близько 12000, щоб додати жіночі версії.

Важливість побудови гендерно чутливої комунікації визнають вищі навчальні заклади різних країн світу, зокрема, Австрії, Швейцарії. Інклюзивний мовний посібник, розроблений Базельским університетом, найстарішим університетом Швейцарії, також охоплює питання, що стосуються несексистської мови. Віденський університет також має керівні принципи та рекомендації щодо використання гендерно-інклюзивної мови.

CEU (Центральноєвропейський університет) нещодавно розпочав кампанію, в якій йшлося про важливість використання правильних займенників у повсякденному спілкуванні. Інформаційний імпульс кампанії було зосереджено на ціннісних основах виховання толерантності як шанобливого способу спілкування та звернення до людей.

Мета статті. Автор статті ставить за мету дослідити зміст гендерно чутливої комунікації в секторі безпеки і оборони; розглянути зусилля міжнародних організацій та державних інституцій у напрямку інтеграції на стратегічному рівні питання гендерно чутливих комунікацій; запропонувати авторське визначення поняття «гендерно чутливі комунікацій»; обгрунтувати гендерну чутливість інститутів сектору безпеки і оборони як одну з важливих передумов забезпечення національної безпеки.

Аналіз останніх досліджень і публікацій. Гендерні дослідження у сфері національної безпеки $є$ відносно новим видом наукового пошуку. На сучасному етапі розвитку теорії безпеки та теорії управління гендерний підхід стає незмінним компонентом комунікації фахівців структур сектору безпеки і оборони із громадянським суспільством і об'єктом наукових досліджень. У вітчизняній науці можна виділити роботи наступних авторів, що присвятили свої наукові 
пошуки тематики гендерної політики: М. Бастік, М.Білинська, Л. Гонюкова, О. Горошко, І. Жеребкіної, К. Левченко, Н. Коупленд, О. Суслової та ін.. Філософські аспекти вживання гендерно чутливої мови вивчав Дженіс Моултон.

Хоча жінки відіграють активну роль у всіх сферах суспільства, все ще часто використовується мова, яка ігнорує або мінімізує їх внесок. Саме з цих причин планування комунікацій має відбуватися так само, як і планування будь-якої іншої діяльності державних інституцій. Розуміння такого стану справ поступово знаходить своє відображення на законодавчому рівні. Так, у Доктрині інформаційної безпеки України [3] зафіксовано поняття стратегічні комунікації «скоординоване і належне використання комунікативних можливостей держави публічної дипломатії, зв'язків із громадськістю, військових зв'язків із громадськістю, інформаційних та психологічних операцій, заходів, спрямованих на просування цілей держави». Ключовими у наведеному визначенні є слова координація і комунікація. Така узгоджена діяльність та координація заходів, які мають проводитись інституціями сектору безпеки та оборони, має враховувати гендерний контекст.

Комплексний підхід до гендерної інтеграції передбачає застосування єдиної стратегії комунікацій на всіх рівнях - стратегічному, оперативному, тактичному. Важливо вибудовувати гендерно чутливі комунікації, які здатні задовольнити конкретні потреби у безпеці кожної категорії населення.

Для цього необхідно вводити обов'язкове системне навчання 3 підвищення гендерної обізнаності фахівців підрозділів, що займаються стратегічними комунікаціями в структурах сектору безпеки та оборони. Одним із прикладних питань, яке дуже впливає на просування гендерної рівності, є застосування фемінітивів в мові в контексті назв посад, які займають, наприклад, правоохоронці-жінки, в зверненнях до них та описі их посад в журналістських сюжетах і статтях.

Важливим кроком у формуванні гендерно чутливого мовного коду став Наказ Міністерства економіки № 1574 від 18 серпня 2020 року «Про затвердження Зміни № 9 до національного класифікатора ДК 003:2010» [4], в якому зазначено, що «при внесенні запису про назву роботи до кадрової документації окремого працівника, професійні назви робіт можуть бути адаптовані для позначення жіночої статі особи, яка виконує відповідні роботи». Утворення фемінітивів відбувається відповідно до пункту 4 параграфа 32 Українського правопису, схваленого постановою Кабінет Міністрів України № 437 від 22 травня 2019 року, в якому закріплено правомірність вживаності іменникових суфіксів -К-, -ИЦ-(Я), -ИН-(Я), -ЕС, за допомогою яких від іменників чоловічого роду утворюються іменники на означення осіб жіночої статі.

Не менш важливо і те, що 16 вересня 2020 року Кабінет Міністрів України прийняв розпорядження «Про схвалення Концепції комунікації у сфері гендерної рівності» [5], реалізація якої розрахована на період до 2025 року. Пропонована модель комунікації являє собою так звану дорожню карту з ведення комунікацій,

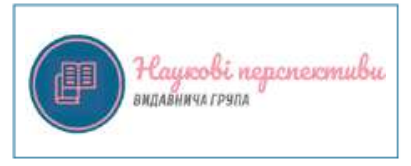


яка відповідатиме національному контексту.

Реалізація Концепції буде здійснюватися за допомогою таких інструментів, як: взаємодія з пресою, телерадіомовленням, інтернет-виданнями, соціальними мережами, інформаційними агентствами; поширення рекламних матеріалів та поліграфічної продукції; проведення публічних виступів, дискусій; співпраця 3 громадськими об'єднаннями та міжнародними організаціями, депутатами, Збройними Силами, профспілками, роботодавцями, науковцями, експертами, представниками іноземних урядових інституцій, послами тощо.

Наскрізний характер питань гендерної рівності також ілюструє включення його в Стратегію цифрової трансформації миротворчих операцій ООН. Серед принципів, якими керується Стратегія, окреме місце посідає гендерно чутливий принцип: розробка та використання технологічного фактору 3 урахуванням гендерних аспектів, грамотності та упередженості.

За визначенням, яке наведено у Посібнику «Гендерний аудит для громадських організацій» [6] гендерно чутлива мова (gender-sensitive language) мова, у якій відсутні прояви сексизму та в якій використовуються фемінітиви терміни, що позначають жіночі ролі, насамперед на ринку праці (наприклад: менеджерка, керівниця, директорка, координаторка тощо).

3 точки зору досягнення гендерної нейтральності в Україні найбільший прогрес було досягнуто в назвах професій. ДСНС презентувала перший в Україні окремо виданий словничок фемінітивів для прес-офіцерів та прес-офіцерок територіальних управлінь Служби. Використання фемінітивів у назвах професій дає можливість візуалізувати участь жінки в нашому суспільному житті.

На противагу гендерно чутливим комунікаціям існує термін «інтолерантні гендерні комунікації», який використовують комунікатори з метою приниження гідності людини або спільнот, невизнання права бути «іншим»; демонстрації домінування власної ціннісної (зокрема гендерної) системи над іншими.

Реалізація гендерної рівності в письмовій та усній мові досягається, коли жінки і чоловіки, а також ті, хто не відповідає бінарній гендерній системі, стають видимими і розглядаються на мові як люди рівної цінності, гідності, цілісності і поваги [7].

Тобто, гендерно чутлива мова означає писати та говорити таким чином, щоб не дискримінувати або не маргіналізувати людей за ознакою статі, а також не транслювати і не продовжувати гендерні стереотипи.

У Мовному посібнику НАТО зазначається, що використання гендерно включеної мови може[8]:

- кинути виклик несвідомому упередженню та припущенням щодо гендерних ролей у суспільстві;

- закласти основу для досягнення більшої гендерної рівності;

- підвищити обізнаність про те, як мова впливає на нашу поведінку та ставлення.

Як глобальний суб’єкт захисту прав жінок і дівчаток, Структура «ООН- 
жінки» визнає використання мови 3 урахуванням гендерних аспектів у всіх контекстах, у тому числі і в безпековому. Суть гендерно-інклюзивної мови полягає в однаковому ставленні до жінок і чоловіків та нульовій толерантності до гендерних стереотипів.

На офіційному сайті Структури «ООН-жінки» доступний для онлайн пошуку словник гендерно-чутливої лексики, який включає близько 650 термінів англійською, французькою, арабською та іспанською мовами. Термін можна шукати за допомогою пошуку «Знайти термін» або за абеткою.

В оцінці гендерної чутливості своїх комунікацій ЮНІСЕФ визначає ключові кроки, яких слід дотримуватися. При розробці дизайну матеріалів і повідомлень слід використовувати трансформаційний підхід - той, який дозволяє оскаржувати та змінювати соціальні норми, що стосуються статі. Такий підхід є необхідністю при проектуванні комунікаційних втручань.

Досвід міжнародних програм, що сприяють гендерно чутливій комунікації, підштовхнув структури сектору безпеки i оборони до внесення змін, що формалізують офіційне вживання фемінітивів. Внесення відповідних змін до установчих документів безпекових інституцій $\epsilon$ нагальним стратегічним завданням, оскільки:

1) визначає жінок як значущу соціальну (професійну) групу і підвищує їх видимість у професії

2) руйнує стереотипи, оскільки окреслює спектр областей, де жінки визнані як професіоналки;

3) мотивує жінок брати участь в нових професійних сферах.

Слід розуміти, що гендерно чутливі комунікації базуються на стратегіях поступового реформування мови - фемінізації (послідовне вживання фемінітивів i відповідне уникнення загального чоловічого роду) i нейтралізації. Тобто, замість «керівники та керівниці» можна сказати «керівництво». Інші приклади використання збірних понять або інших лексичних засобів - «панство», «слухацька аудиторія», «кібервійська».

За твердженням Голови Національної комісії зі стандартів державної мови Орисі Демської, присутність фемінітивів у мові $є$ маркерами гендерної рівності в суспільстві. Якщо чоловік і жінка можуть виконувати однакові функції і нести однакову відповідальність в соціальній, державній, громадській сфері, це завжди відображено в мові. А в українському суспільстві, для якого демократичний устрій $\epsilon$ типовим, фемінітиви в мові мають дуже давню традицію. Інша річ, що за радянський період у нас явно домінувала маскулінна політична культура, яка не потребувала забезпечення жіночими назвами. Але сьогодні ми говоримо про гендерну рівність i гендерну справедливість, яка, відповідно, відображатиметься в мові.

На думку О. Малахової, використання фемінітивів для жінки не $\epsilon$ образливим, а навпаки, значною мірою демонструє, що вона $\epsilon$ повноцінно суб'єктна в процесах.

Закон України «Про засади запобігання та протидії дискримінації в Україні» [9] 
пропонує визначення понять дискримінація, непряма дискримінація та утиск.

Суттєвою складовою дискримінації та утиску є комунікативна агресія - дії одного 3 комунікаторів, що мають на меті отримання переваг статусного, особистого, ділового, психологічного або іншого характеру. Комунікативна агресія базується на порушенні комунікативних норм та ігноруванні комунікативних принципів співробітництва та взаємодії, а також принципу ввічливості.

Габріель Дієвальд, професор лінгвістики з Ганноверського університету, вважає, що рішуче протистояння гендерно-нейтральній мові випливає 3 того, що "мова, відповідна статі, є претензією на владу".

Із посиленням соціальних рухів в Україні, у тому числі й за права жінок, змінилися норми суспільно-політичного й ділового мовлення $-\epsilon$ підстави говорити про фемінізацію сучасної української мови: постійно зростає кількість жіночих іменувань, відповідно до збільшення кількості жінок у різних сферах діяльності, зокрема СБО.

Тож на стратегічному рівні управління важливо інтегрувати питання гендерно чутливих комунікацій в доктринальні документи сфери національної безпеки; планувати та координувати гендерно чутливі комунікації як на рівні державної, так й міжвідомчої взаємодії, враховуючи аспекти гендерної чутливості; внести зміни до установчих документів безпекових інституцій щодо закріплення офіційного вживання фемінітивів на позначеннях професій, посад та військових звань.

Європейський інститут гендерної рівності рекомендує законодавцям та політикам надавати перевагу використанню гендерно чутливої мови. Офіс публікацій ЄС опублікував інструкції з гендерно нейтральної мови у своєму посібнику Inter-institutional Style Guid, де основна увага приділяється використанню гендерно нейтральної мови в діловодстві. Наразі згадані вище інструкції доступні лише англійською мовою.

Крім цього, Європейський інститут гендерної рівності (ЕIGE) проводить вікторину, яка дозволяє охочим перевірити свої вміння розпізнавати гендерно нечутливу мову.

Також варто зазначити, що багато інституцій (наприклад, університети чи міністерства) у країнах-членах $\mathrm{CC}$ видають вказівки щодо використання недискримінаційної та гендерно нейтральної мови.

Португальська державна телерадіокомпанія провела тренінг 3 гендерних питань рівність та використання несексистської мови для своїх працівників. Міністерство науки, досліджень та економіки Австрії видало настанови щодо недискримінаційної комунікації щодо статі, віку та етнічної приналежності. Вища рада з питань гендерної рівності у Франції опублікувала вказівки щодо того, як уникати гендерних стереотипів у публічному спілкуванні.

Зважаючи на розглянуте вище, пропонується авторське визначення поняття «гендерно чутливі комунікацій» як нового комунікативного стандарту; 
інструменту досягнення гендерної рівності, яким рекомендована відмова від використання слів, що передбачають гендерну конотацію.???

Відповідно до Річної національної програми під егідою Комісії УкраїнаНАТО, гендерна тематика також має бути включена до системи підготовки та підвищення кваліфікації особового складу сектору безпеки і оборони України.

В рамках Проекту ООН Жінки «Гендерна рівність у центрі реформ, миру та безпеки», що здійснюється за фінансової підтримки Швеції, були розроблені «Методичні рекомендації з інтеграції гендерних підходів в систему підготовки фахівців для сектору безпеки і оборони України». Автори публікації поряд із гендерно чутливими комунікаціями виокремлюють інтолерантні гендерні комунікації як такі, що спрямовані на приниження гідності людини або спільнот, невизнання права бути «іншим»; демонстрація переваг власної ціннісної (зокрема гендерної) системи над іншими.

Інформація щодо гендерної чутливості структур сектору безпеки і оборони може бути отримана з таких джерел:

- звіти вітчизняних та іноземних наглядових органів, а також органів із розгляду скарг;

- звіти місцевих і міжнародних НУО;

- усі доступні опитування громадської думки або картки обліку громадян;

- опитування громадськості, місцевих та міжнародних НУО;

- мініопитування;

- опитування співробітників структур сектору безпеки та оборони, відповідальних за діяльність з інформування громадськості;

- аналіз цілей, місії та стратегії структур сектору безпеки та оборони щодо взаємодії з громадськістю, які позиціоновані на офіційних сайтах;

- опитування фокус-груп або певних прошарків суспільства;

- розгляд порядку денного і протоколів засідань, що проводяться структурою сектору безпеки та оборони спільно з громадськістю (зокрема дані осіб, залучених до консультації);

- пошук доказів, що структура сектору безпеки та оборони враховує інтереси громадськості в програмах навчання та практичній діяльності.

Висновки. Комунікація 3 питань гендерної рівності $\epsilon$ ефективним інструментом реалізації державної гендерної політики, і потребує особливої уваги на основі науково обгрунтованого концепту ii розвитку. Останній час можна спостерігати розширення антигендерних течій та поглядів, в українському суспільстві, що підтримуються політиками, релігійними організаціями і є виявом гібридних загроз.

Вважаємо, ми дійшли висновку про те, що структурам сектору безпеки i оборони слід розвивати свої комунікаційні спроможності 3 урахуванням гендерної складової. Гендерно-чутлива комунікація уникає поширення стереотипів щодо ролей, поведінки чоловіків та жінок. Рівність і внесок жінок у суспільний розвиток повинно бути враховане у візуальних образах, зображеннях, 
наприклад, в оголошеннях про проведення конкурсу на посади державної служби в патрульній поліції. Важливим є присутність на таких оголошеннях фото як чоловіків так і жінок поліцейських. Такі «гендерні лінзи» допоможуть розвіювати стереотипні уявлення про чоловіка, як представника певної професії, що не дозволяє жінкам бути помітними у суспільному житті.

Наразі в Україні відбувається розвиток гендерно орієнтованої політики у всіх сферах суспільного життя. Прискорити цей процес можуть комунікаційні команди відомств сектору безпеки і оборони під час створення контенту для офіційних відомчих сторінок. Наприклад, до Дня захисників і захисниць України важливо зробити акцент на внеску і чоловіків і жінок військових, поліцейських у безпеку громадян як в умовах ведення війни, так і в мирний час.

\section{Jimepamypa:}

1. У НОВИНАХ УКРАЇНСЬКИХ ЗМІ ЖІНОК ЗГАДУЮТЬ ВТРИЧІ РІДШЕ, НІЖ ЧОЛОВІКІВ - ДОСЛІДЖЕННЯ. URL: https://imi.org.ua/monitorings/u-novynah-ukrajinskyh-zmizhinok-zhaduyut-vtrychi-ridshe-nizh-cholovikiv-doslidzhennya-i28377

2. Debate over gender-neutral language divides Germany. URL: https://www.politico.eu/article/debate-over-gender-inclusive-neutral-language-divides-germany/

3. Про Доктрину інформаційної безпеки України. Указ Президента України від 25 лютого 2017 року № 47/2017. URL: http://www.president.gov.ua/documents/472017-21374

4. «Про затвердження Зміни № 9 до національного класифікатора ДК 003:2010»: Наказ Міністерства економіки України від 18.08.2020 № 1574

5. Про схвалення Концепції комунікації у сфері гендерної рівності: розпорядження Кабінету Міністрів України від 16 вересня 2020 p. № 1128-p. URL: https://zakon.rada.gov.ua/laws/show/1128-2020- \%D1\%80\#Text.

6. Гендерний аудит для громадських організацій / авт.: Л. Максимович, М. Чумало. 1 вид. Львів: 2019. 64 с.

7. European Institute for Gender Equality. URL: https://eige.europa.eu/thesaurus/ terms/1215?utm_source=newsletter\&utm_medium=email\&utm_campaign=eu_leaders_use_the_gend er_equality_index_in_their_work\&utm_term=2018-09-19

8. NATO Gender-Inclusive Language Manual URL: https://www.nato.int/nato_static_fl2014/ assets/pictures/images_mfu/2021/5/pdf/210514-GIL-Manual_en.pdf

9. Про засади запобігання та протидії дискримінації в Україні: Закон від 06.09.2012 № 5207-VI // [Електронний ресурс]. https://zakon.rada.gov.ua/laws/show/5207-17\#Text

\section{References:}

1. U NOVINAH UKRAÏNS"KIH ZMI ZhINOK ZGADUJuT" VTRIChI RIDShE, NIZh ChOLOVIKIV - DOSLIDZhENNJa [IN THE NEWS OF UKRAINIAN MEDIA, WOMEN ARE MENTIONED THREE TIMES LESS THAN MEN ABOUT MEN - RESEARCH]. Retrieved from https://imi.org.ua/monitorings/u-novynah-ukrajinskyh-zmi-zhinok-zhaduyut-vtrychi-ridshe-nizhcholovikiv-doslidzhennya-i28377 [in Ukrainian].

2. Debate over gender-neutral language divides Germany. URL: https://www.politico.eu/article/debate-over-gender-inclusive-neutral-language-divides-germany/

3. Ukaz Prezidenta Ukraïni "Pro Doktrinu informacijnoï bezpeki Ukraïni" [Decree of the President of Ukraine "On the Doctrine of Information Security of Ukraine"]. (n.d.). zakon.rada.gov.ua. Retrieved from http://www.president.gov.ua/documents/472017-21374 [in Ukrainian]. 
4. Nakaz Ministerstva ekonomiki Ukraïni «Pro zatverdzhennja Zmini № 9 do nacional'nogo klasifikatora DK 003:2010» [Order of the Ministry of Economy of Ukraine "On approval of Amendment № 9 to the national classifier DK 003: 2010"]. (n.d.). zakon.rada.gov.ua. Retrieved from https://zakon.rada.gov.ua/rada/show/v1574915-20\#Text [in Ukrainian].

5. Rozporjadzhennja Kabinetu Ministriv Ukraïni "Pro shvalennja Koncepciï komunikaciï u sferi gendernoï rivnosti" [Order of the Cabinet of Ministers of Ukraine "On approval of the Concept of communication in the field of gender equality"]. (n.d.). zakon.rada.gov.ua. Retrieved from https://zakon.rada.gov.ua/laws/show/1128-2020- \%D1\%80\#Text [in Ukrainian].

6. Maksimovich, L. \& Chumalo, M (2019). Iendernij audit dlja gromads'kih organizacij [Gender audit for public organization]. Lviv: «1 vid. L'viv» [in Ukrainian].

7. European Institute for Gender Equality. URL: https://eige.europa.eu/thesaurus/ terms/1215?utm_source=newsletter\&utm_medium=email\&utm_campaign=eu_leaders_use_the_gend er_equality_index_in_their_work\&utm_term=2018-09-19

8. NATO Gender-Inclusive Language Manual URL: https://www.nato.int/nato_static_fl2014/ assets/pictures/images_mfu/2021/5/pdf/210514-GIL-Manual_en.pdf

9. Zakon Ukrainy «Pro zasadi zapobigannja ta protidiï diskriminaciï v Ukraïni» [The Law of Ukraine «On the principles of preventing and combating discrimination in Ukraine»]. (n.d.). zakon.rada.gov.ua. Retrieved from https://zakon.rada.gov.ua/laws/show/5207-17\#Text [in Ukrainian]. 